\title{
Market value of firms and R\&D investment: Theoretical overview and empirical estimation for the panel of countries
}

\author{
Dushko Josheski ${ }^{\star}$ and Marija Magdinceva Sopova \\ Goce Delcev University - Stip, Macedonia. \\ Accepted 24 February, 2013
}

\begin{abstract}
The aim of this paper is to investigate the issue of R\&D investment and the market value of firms. This idea dates back from Arrow paper, later developed by Paul Romer, but in the area of economic growth. Zvi Griliches in 1979 first introduced the production function, which was later used in a vast literature from this area. In the theoretical section of this paper, Tobin's original model and Abel's (1984) model were described. These models relate Tobin's quotient with intangible assets of the company. In the empirical part, cross-section time series model (Feasible Generalized Least Squares Model) was developed for a panel (a total of 11 panels) of countries in Europe including UK and Turkey. Later, we test that model by estimating the marginal effects of R\&D investment with Tobin's q on a small economy such as $R$. Macedonia. The results exert positive and statistically significant relationship between market value of the firms and R\&D investment.
\end{abstract}

Key words: Tobin's q, R\&D, knowledge absorption, feasible generalized least squares model, replacement value, market value.

\section{INTRODUCTION AND LITERATURE SURVEY}

In this paper, we examined the issue of $R \& D$ investment and the market value of the firm. R\&D investment is different than other ordinary investments. According to Hall and Lerner $(2009)^{1}$, fifty percent or more of R\&D spending is on salaries of highly educated scientists and engineers. The idea comes from Arrow $(1962)^{2}$, who introduced growth model in which the per capita growth rate depends on the capital per worker and the average of the stock of capital of other workers ${ }^{3}$. In the empirical literature form this area, one significant contribution observed was the paper written by Connolly and Hirschey (2005). When comparing the R\&D effect on Tobin's Q, they find positive and statistically significant relationship

\footnotetext{
1 Hall, B., H. \& Lerner, J, (2010). "The Financing of R\&D and Innovation,"UNU-MERIT Working Paper Series 012, United Nations University, Maastricht Economic and social Research and training centre on Innovation and Technology.

2 Arrow, K.J. (1962). "The Economic Implications of Learning by Doing," American Economic Review, May 96(2): pp. 308-312.

${ }^{3} y=A k^{1-\alpha}(\bar{k})^{\alpha} \quad 0<\alpha<1$ in equilibrium $k=\bar{k}$
}

across sample of manufacturing and non-manufacturing firms, and the evidence found was statistically significant and it showed positive influence of R\&D on Tobin's $q^{4}$.

Earlier, Connolly and Hirschey $(1984)^{5}$ considered relation between market structure, $R \& D$ and profits. They found positive effect of R\&D on profit, but also observed negative $R \& D$ concentration interaction effect ${ }^{6}$. As was observed in this study as regards the earlier study of Arrow (1962) and the later study of Romer (1990),

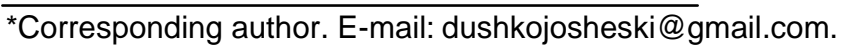

\footnotetext{
${ }^{4}$ Connolly, R.,Hirschey,M.,(2005), Firm size and the effect of R\&D on Tobin's q, R\&D Managemenl 35. 2, 2005. cg Blackwell Publishing Ltd, 2005. Published by Blackwell Publishing Ltd,

${ }^{5}$ Connolly, R.,Hirschey,M.,1984), R \& D, Market Structure and Profits: A Value-Based Approach, The Review of Economics and Statistics, Vol. 66, No. 4. (Nov., 1984), pp. 682-686.

${ }^{6}$ The firms in the more concentrated industries are less efficient researchers, or are willing to take riskier projects.
} 
research and development expenditures were valued in economic growth perspective (Warusawitharana, 2008) ${ }^{7}$. Also the same production that Griliches $(1979)^{8}$ used is vastly used in this literature; the functional form is as follows: $Y=F(K, L, T, u)$, here $K$ and $L$ are labor and capital inputs, and $T$ is a measure of the current state of technical knowledge, and $u$ are all unmeasured determinants of output and productivity. James Tobin in 1978 also explains that $q$ is a measure of profitable investment opportunities. Later Griliches and Cockburn (1988) relate the value of the firm with Tobin's q, as follows:

\section{$V=q(\tan$ gible capital, int angible capital $)$}

So in this paper ${ }^{9}$, $\mathrm{q}$ is related also to intangible capital. Megna and Klock (1993) ${ }^{10}$ also examined the contribution of R\&D stocks of the firms in semi-conductor industry, and found positive externalities of their own R\&D stock of the firms as well as the rivals stock of R\&D on Tobin's q, but rivals patents negatively influenced Tobin's Q. This reveals that patents and R\&D are distinctive measures of intangible assets, because patents are marketable and R\&D are just initiative. Hall (1998) ${ }^{11}$ introduced CobbDouglass production form with Tobin's q:

$$
b V_{t}(T A, I A)=q_{t} T A^{\sigma-a t} I A_{t}^{a t}
$$

Here TA is tangible assets, and IA is intangible assets. Intertemporal elasticity of substitution is given by $\sigma$, symbol, while in logarithms this function is presented by the following functional form:

$$
\log b V_{t}=\log q_{t}+\sigma_{t} \log T A+\alpha_{t}(\log I A / T A)
$$

Later Hall et al. (2007) ${ }^{12}$ explained that the functional form of intertemporal maximization with several capital goods is hard to derive, and most of the literature relies on the assumption that market valuation equation takes

\footnotetext{
${ }^{7}$ Warusawitharana,M.,(2008), Research and Development, Profits and Firm Value:A Structural Estimation, Division of Research and Statistics, Board of Governors of the Federal Reserve System

${ }^{8}$ Griliches, Zvi(1979), R\&D and Productivity: The Econometric Evidence, Chapter: Issues in Assessing the

Contribution of Research and Development to Productivity Growth

9 Cockburn, Iain \& Griliches, Zvi, (1988). "Industry Effects and Appropriability Measures in the Stock Market's Valuation of R\&D and Patents,"American Economic Review, American Economic Association, vol. 78(2), pages 419-23, May

${ }^{10}$ Megna, P. and Klock, M. 1993. The Impact of Intangible capital on Tobin's q in the Semiconductor Industry, The American Economic Review 83(2): 265 269.

${ }^{11}$ Hall, B.,(1998), Innovation and market value, University California Berkeley

${ }^{12}$ Bronwyn H. Hall \& Grid Thoma \& Salvatore Torrisi, 2007. "The market value of patents and R\&D: Evidence from European firms,"NBER Working Papers 13426, National Bureau of Economic Research, Inc.
}

log-linear, or log-log presentation. Hall et al. (2007) make a distinction between knowledge capital and physical assets. Adaptive multiplicative separable function can be written as follows (Damianova, 2005) ${ }^{13}$ :

$b V_{t}=\left(T A_{t}\right)^{\beta_{1}} \sum_{\theta=1}^{T}\left(I A_{t-\theta}\right)^{\beta_{2}, \theta}$

Here $\theta$ is the time lag, denoting that production of knowledge capital is different than production of physical capital since it involves projects with durations of several years.

\section{Tobin's q, the market value of the firms}

Tobin's $q$ is an indicator of the limit for the lowest market value of enterprises. It is calculated as the rate between the market value of the enterprise and the cost of replacement assets in the assets. It is the quotient of the market value of a capital (activity, share or real capital) and reproduction costs for the specified capital. Enterprises, activity or shares are normally being purchased when the costs of purchase are lower than the initial construction costs-costs.

Anyone who wants to invest in the financial market is using this coefficient. At the beginning, it was believed that Tobin's $q$ is an indicator of the impact of interest rate of consumer's behavior and enterprises in the financial market. The higher the value of Tobin's q, the greater the investment opportunities. If there is increase in the value of Tobin's q, there will be an increase in the financial power of the consumers, population and the state, in general. Increased financial power on the one side causes an increase in the consumption.

Lower Tobin's q means reducing investment consumption and reducing investment in research and development. Ideally, the market value of the enterprise and the cost of replacement capital will be equal or nearly equal, while it maintains a state of equilibrium. When Tobin's $q$ is 1 , there is a balance between the cost of the use of assets and profits. The market value of existing enterprises is expressed by the capital cost of replacing the existing relationship with Tobin's q ratio. According to this, the value of Tobin's $q$ ratio should be at least 1 . When the value of Tobin's $q$ ratio is more than 1 , it recommends additional investment because profit is higher than the cost price for the use of invested assets. At the same time, less than 1 Tobin's q ratio shows that the cost invested by enterprises in the capital cannot be affected and the market value of the company would be lower than the invested assets.

In view of these enterprises, the best enterprises would reduce the costs through sales. Tobin's q ratio is applied

\footnotetext{
13 Damianova,K., (2005), The Conditional Value of R\&D Investments, National Centre of Competence in Research Financial Valuation and Risk Management.
} 
as a reliable indicator for assessing the market value of enterprises. But the assessment of the future activities of the enterprises is the best when Tobin's $q$ ratio is applied in combination with other indicators.

\section{$R \& D$ and market value of the firm}

R\&D investment creates "intangible" capital, and this affects the valuation of the company by the investors. Market value of the firm will be treated as an indicator for the success of the company, but will be done only partially (Griliches, 1981) ${ }^{14}$. Thus, the "definitional" model by Zvi Griliches is used here:

$$
M V=q(T A+I A)
$$

Here, MV represents the market value of the firm (equity plus debt), which is equal to $q$ (which represents the current market valuation coefficient of the company's assets), multiplied by TA which represents tangible assets, plus IA intangible assets. From the expression above, we have the following: $q=\frac{M V}{(T A+I A)}$ that is, the expression for Tobin's Q (quotient). Here, we state that IA -intangible assets are the "stock of knowledge" of the companies. The reason why in the q-theory, $Q>1, Q$ can be above 1, is because of the intangible assets of the company. For the early Keynesians, the position of the current cash flow and liquid assets was important as a major determinant of investment (Akerlof, 2007) ${ }^{15}$. But later Modigliani-Miller, same as the other existing contemporary literature, assumed that the firm's financial position, is not important in investment decision, that is, investment is independent of current cash flow and liquidity position. In the original paper by Tobin (1969), firms invested up to the point where marginal cost of a new unit of capital is the valuation of such a unit capital in the market (Akerlof, 2007). Tobin, like in neoclassical growth theory, assumes some natural rate of growth $y_{n}$, and the equation: $y_{k} * K=s Y$, where $\mathrm{s}$, is the savings ratio (marginal propensity to save), $Y$ is the real income, $\bar{R}$ is the marginal efficiency of the capital stock, and $\bar{R}=r K$ where $\mathrm{r}$ is the interest rate or return of the capital stock. In such a case, $\mathrm{q}=1$, and investment equals saving. While Tobin defines $\bar{R}=r q$, in Tobin's paper $\mathrm{q}$ is the market price of existing capital goods, so $r q=r K$, that is, $q=K$, so the firm should invest up to the point where the marginal unit of capital is equal to valuation of such a unit of capital in the stock market.

\footnotetext{
${ }^{14}$ Griliches, Z. (1981), 'Market value, R\&D and patents', Economics Letters, 7 (2), 183-187

${ }_{15}$ Akerlof, George,(2007),Missing motivation in macroeconomics,American Economic Review, 2007, vol. 97, issue 1, pages 5-36.
}

Thus, investment is independent of the finance situation of the firm.

In Tobin's interpretation of Keynesian LM curve, he introduced $\frac{\bar{R}}{q}$ as the speed of investment that should be equal in equilibrium with $\frac{r}{K}$, or $\frac{\bar{R}}{q}=\frac{r}{K}$. Later on in his 1977 paper, Tobin defines marginal efficiency of capital as follows:

$$
V=\int_{0}^{\infty} E(t) e^{-\bar{R} t} d t
$$

Here, $V$ is the cost of capital (replacement value) and $E(t)$ is the expected future earnings. We used the formula for integration by parts ${ }^{16}$, and replace it with

$$
u=t E, d v=e^{-t \bar{R}} \quad d x \text {, or } d u=E^{*} \quad d t, v=-\frac{e^{-t \bar{R}}}{\bar{R}} .
$$

We replace $\int \mathbf{u d v}=-\frac{\mathbf{t E} * \mathrm{e}^{-\mathrm{t} \overline{\mathbf{R}}}}{\overline{\mathbf{R}}}-\int-\frac{\mathbf{E} * \mathrm{e}^{-\mathrm{t} \overline{\mathbf{R}}}}{\overline{\mathbf{R}}} \mathrm{dt}$ for the second half of the equation $\int-\frac{E^{*} e^{-t \bar{R}}}{\bar{R}} d t$. If we replace $u=-\mathrm{t} \overline{\mathrm{R}}$, we should find a equation for $d u=-R d t$, that is, $\frac{d u}{-R}=d t$. Now, if we replace $\int-\frac{\mathrm{E}^{*} \mathrm{e}^{\mathrm{u}}}{\overline{\mathrm{R}}} *-\frac{1}{\bar{R}} d u$, we can simplify the integrand $\int \frac{\mathrm{E}^{*} \mathrm{e}^{\mathrm{u}}}{\overline{\mathrm{R}}^{2}} d u$. If we substitute for $\mathrm{u}$, we solve $\frac{\mathrm{E}^{*} \mathrm{e}^{-\overline{\mathrm{R}} \mathrm{t}}}{\overline{\mathrm{R}}^{2}}+C$, but if we substitute in the formula for integration by parts $-\frac{\mathbf{t E} * \mathrm{e}^{-\mathbf{t} \overline{\mathbf{R}}}}{\overline{\mathbf{R}}}-\frac{\mathbf{E} * \mathrm{e}^{-\overline{\mathbf{R}} \mathbf{t}}}{\overline{\mathbf{R}}^{2}}+C$, now to evaluate the integral we evaluate the upper solution from lower solution. We multiply upper bound solution by the expression, and then we subtract down bound solution:

$$
-(\infty) \frac{\mathbf{t E} * \mathbf{e}^{-\infty \overline{\mathbf{R}}}}{\overline{\mathbf{R}}}-\frac{\mathbf{E} * \mathbf{e}^{-\overline{\mathbf{R}} \infty}}{\overline{\mathbf{R}}^{2}}-\left[-(\mathbf{O}) \frac{\mathbf{t E} * \mathbf{e}^{-\mathbf{O} \overline{\mathbf{R}}}}{\overline{\mathbf{R}}}-\frac{\mathbf{E} * \mathbf{e}^{-\overline{\mathbf{R}} \mathbf{O}}}{\overline{\mathbf{R}}^{2}}\right]
$$

When we simplify $-\frac{E\left(\overline{\mathrm{R}} \mathrm{e}^{-\bar{R}}+e^{-\bar{R}}-1\right)}{\bar{R}^{2}}$. Now Tobin (1977) presents market value of capital goods of the firm and the expression is presented in the following expression: $M V=\int_{0}^{\infty} E(t) e^{-r t} d t, \mathrm{E}(\mathrm{t})$ is constant, then
$\mathrm{V}=\mathrm{E} / \overline{\mathrm{R}}$, and $\mathrm{MV}=\mathrm{E} / \mathrm{r}$. Consequently, $\frac{M V}{V}=\frac{R}{r}$. This is $16 \quad \int_{0}^{\infty} f(t) g^{\prime}(t) d t=f(t) g(t)-\int_{0}^{\infty} f^{\prime}(t) g(t) d t$ $\int u d v=u v-\int v d u$ 
Table 1. Tobin's q for the selected countries.

\begin{tabular}{|c|c|c|c|c|c|c|c|c|c|c|c|c|c|}
\hline \multicolumn{14}{|c|}{ Tobin's q } \\
\hline Year & Austria & Belgium & Cyprus & Denmark & France & Germany & Greece & Italy & Luxembourg & Slovenia & Switzerland & Turkey & $\begin{array}{c}\text { United } \\
\text { Kingdom }\end{array}$ \\
\hline 1993 & 1 & 1.04 & 1.01 & 1.03 & 1.04 & 1.02 & 1 & 1 & 1.1 & 0.96 & 1.07 & 1.06 & 1.09 \\
\hline 1994 & 1 & 1.04 & 1.02 & 1.03 & 1.04 & 1.02 & 1.01 & 1.01 & 1.12 & 0.95 & 1.07 & 1.04 & 1.09 \\
\hline 1995 & 1 & 1.04 & 1.05 & 1.03 & 1.04 & 1.02 & 1.01 & 1.01 & 1.11 & 0.89 & 1.08 & 1.03 & 1.09 \\
\hline 1996 & 1 & 1.04 & 1.04 & 1.04 & 1.04 & 1.02 & 1.02 & 1.01 & 1.11 & 0.92 & 1.08 & 1.04 & 1.1 \\
\hline 1997 & 1.01 & 1.05 & 1.04 & 1.05 & 1.05 & 1.04 & 1.03 & 1.03 & 1.12 & 0.97 & 1.1 & 1.07 & 1.1 \\
\hline 1998 & 1 & 1.08 & 1.05 & 1.05 & 1.07 & 1.05 & 1.07 & 1.05 & 1.12 & 0.98 & 1.11 & 1.04 & 1.1 \\
\hline 1999 & 1 & 1.06 & 1.09 & 1.06 & 1.08 & 1.06 & 1.11 & 1.06 & 1.12 & 0.98 & 1.11 & 1.09 & 1.11 \\
\hline 2000 & 1 & 1.07 & 1.08 & 1.06 & 1.08 & 1.06 & 1.09 & 1.06 & 1.12 & 0.99 & 1.12 & 1.07 & 1.11 \\
\hline 2001 & 0.99 & 1.06 & 1.09 & 1.05 & 1.08 & 1.05 & 1.07 & 1.05 & 1.1 & 0.99 & 1.11 & 1.06 & 1.1 \\
\hline 2002 & 1 & 1.05 & 1.07 & 1.04 & 1.06 & 1.03 & 1.06 & 1.04 & 1.1 & 1.01 & 1.1 & 1.03 & 1.09 \\
\hline 2003 & 1.01 & 1.05 & 1.06 & 1.05 & 1.07 & 1.04 & 1.06 & 1.04 & 1.11 & 1.02 & 1.1 & 1.06 & 1.1 \\
\hline 2004 & 1.03 & 1.06 & 1.05 & 1.05 & 1.07 & 1.04 & 1.06 & 1.04 & 1.11 & 1.03 & 1.1 & 1.03 & 1.09 \\
\hline 2005 & 1.04 & 1.06 & 1.06 & 1.06 & 1.07 & 1.04 & 1.07 & 1.04 & 1.11 & 1.02 & 1.11 & 1.04 & 1.1 \\
\hline 2006 & 1.06 & 1.07 & 1.1 & 1.07 & 1.08 & 1.05 & 1.08 & 1.05 & 1.13 & 1.04 & 1.12 & 1.04 & 1.1 \\
\hline 2007 & 1.06 & 1.07 & 1.12 & 1.07 & 1.08 & 1.05 & 1.08 & 1.04 & 1.15 & 1.06 & 1.11 & 1.05 & 1.1 \\
\hline 2008 & 1.01 & 1.03 & 1.05 & 1.03 & 1.05 & 1.03 & 1.03 & 1.01 & 1.1 & 1.02 & 1.09 & 1.01 & 1.07 \\
\hline 2009 & 0.99 & 1.05 & 1.03 & 1.05 & 1.06 & 1.03 & 1.01 & 1 & 1.12 & 1.02 & 1.11 & 1.05 & 1.09 \\
\hline 2010 & 1.01 & 1.06 & 1.04 & 1.07 & 1.06 & 1.04 & 1.02 & 1 & 1.11 & 1.02 & 1.11 & 1.05 & 1.09 \\
\hline
\end{tabular}

the expression for out quotient Q. Tobin extends the model to macroeconomics (IS-LM) model defining the investment function, which is a change in capital as follows, $\frac{\Delta K}{K}=f(q-\bar{q})+y_{n}, \bar{q}$ is some normal value of $\mathrm{q}$, that is, $\mathbf{q}=1$, while $y_{n}$ is the natural growth rate. And if $q=\bar{q}$, then $\Delta K=y_{n} K$, which represents net investment ${ }^{17}$. Now since we explained market valuation models for the firm, we will add up R\&D to see the causality between the two. Abel (1984) did set up a model of market value of the firm and R\&D. Abel (1984) ${ }^{18}$ uses Bellman value function ${ }^{19}$, for the market value of the firm:

$$
M V\left(T_{t}, p_{t}\right)=\max _{L_{t}, \bar{R}_{t}} E_{t}\left[p_{t} L_{t}^{\alpha} T_{t}^{1-\alpha}-w L_{t}-a \bar{R}_{t}^{2}+\beta V\left(T_{t+1, p_{t+1}}\right)\right]
$$

Here, $E_{t}$ is conditional dynamic expectation, $T_{t}^{1-\alpha}$ is the technology, which is accumulated to produce output, $\bar{R}$ again is the marginal efficiency of capital, but yet it is some R\&D activity, $a \bar{R}_{t}^{2}$ are R\&D expenditures, $w L_{t}$ are the wages of the workers that influence the cash flow of

\footnotetext{
${ }^{17}$ Tobin J, and Brainard W.C.( 1977), Asset Markets and the Cost of Capital, Cowles Foundation Paper 440

Reprinted from Private Values and Public Policy, Essays in Honor of William Fellner, North-Holland, 1977

${ }^{18}$ Abel,B,Andrew (1984),, "R \& D and the Market Value of the Firm: A Note". In R \& D, Patents and Productivity, edited by Zvi Griliches, (1984), 261 - 269.

${ }^{19}$ Bellman equation has been used in economics amongst others also by Edmund Phelps, Robert Lucas, Sargent and others.
}

the company, $p_{t}$ is the price of the output, and $p_{t} L_{t}^{\alpha} T_{t}^{1-\alpha}=\pi$ is the profit of the firm. Abel used the Bellman equation to derive the expression for Tobin's q:

$$
q_{t}=\frac{M V\left(T_{t}, p_{t}\right)-E_{t-1} M V\left(T_{t}, p_{t}\right)}{M V\left(T_{t-1, p_{t-1}}\right)}
$$

Here, $E_{t-1}$ are the expectations from the past period, but $E_{t-1}$ is multiplied by the present value of the firm, meaning that excess return is uncorrelated with any past information (efficient market hypothesis).

\section{METHODOLOGY AND DATA}

The data that were used in this study were collected from World Bank data site ${ }^{20}$. Tobin's q derived its quotient from market value to the replacement cost of their capital ratio. This is known as Tobin's (1969) ${ }^{21}$. Table 1 presents the value of Tobin's q for the selected European countries including United Kingdom and Turkey.

Variables that were used to get the ratio between market value and replacement cost of capital are shown in Table 2. The quotient of Tobin's $q$ in the table for European countries, Turkey and UK was obtained as:

\footnotetext{
${ }^{20} \mathrm{http}$ ://search.worldbank.org/data?qterm=royalty\&language=EN\&format= 21 J.Tobin, (1969). "A general equilibrium approach to monetary theory". Journal of Money Credit and Banking 1 (1): 15-29.
} 
Table 2. Variable description.

\begin{tabular}{ll}
\hline Name of the variable & Variable label \\
\hline $\begin{array}{l}\text { Market capitalization of listed } \\
\text { companies (current US\$) (also }\end{array}$ & $\begin{array}{l}\text { Market capitalization (also known as market value) is the share price times the } \\
\text { number of shares outstanding. Listed domestic companies are the domestically } \\
\text { incorporated companies listed on the country's stock exchanges at the end of the } \\
\text { year. Listed companies do not include investment companies, mutual funds, or } \\
\text { other collective investment vehicles. Data are in current U.S. dollars. }\end{array}$
\end{tabular}

Adjusted savings: consumption of fixed capital (current US\$) (Replacement value)

Royalty and license fees, payments (BoP, current US\$) (knowledge absorption)
Consumption of fixed capital represents the replacement value of capital used up in the process of production.

Royalty and license fees are payments and receipts between residents and nonresidents for the authorized use of intangible, nonproduced, nonfinancial assets and proprietary rights (such as patents, copyrights, trademarks, industrial processes, and franchises) and for the use, through licensing agreements, of produced originals of prototypes (such as films and manuscripts). Data are in current U.S. dollars.

Table 3. Descriptive statistics.

\begin{tabular}{lccccc}
\hline Variable & Observation & Mean & Std. Dev. & Min & Max \\
\hline Tobin's q & 198 & 1.061465 & 0.037177 & 0.99 & 1.15 \\
R\&D & 194 & 20.2958 & 1.950381 & 15.90016 & 23.59306 \\
\hline
\end{tabular}

$q=\frac{\text { Market valne ofthe intakd capital }}{\text { Replacement cost of the capital }}=\frac{\text { Market capitalization of listed companies }}{\text { Adjusted savings: consumption of fixed capital }}$

Then afterwards in the econometric section, we introduced variable Royalty and license fees, payments (BoP, current US\$).

This is a very important variable, because it represents knowledge absorption or R\&D investment for the firms; so we test it empirically to see how it influences value of the firms. In the econometric model specification, we used the following regression (functional form):

Tobin's $q_{i, t}=\beta_{0}+\beta_{1} \log (\text { knowledgeabsorption })_{i, t}+\varepsilon_{i, t}$

In this study, cross-section time series model (that is, panel model) was used, and data were gathered through time $t$, for the panels $i$. The same functional form was subsequently used but in cross-section terms it was adjusted for Macedonia only.

\section{Descriptive statistics}

Here, we publish the descriptive statistics for the 11 panels of countries. Table 3 is given next, which shows the values of Tobin's q and Royalty and license fees, payments. This study used logarithms to adjust the values of market value, replacement cost of the companies $^{22}$, and knowledge absorption of the companies to avoid measurement errors.

From Table 3, we can see that the Tobin's q is moving around 1 . If the market solely reflects the recorded value by the accountants' value of the company, Tobin's $q$ would be around 1. If the value of Tobin's $q>1$, it means that the market is overvaluing the company, and that the company can issue shares with the revenues to invest in capital. In case $\mathrm{q}<1$, it means that the market is undervaluing the company, and the market value is less than the recorded value of the company. From the table for Tobin's q quotient in the study's methodology, we can see that Slovenia in the 1990s and 1993 to the year 2000 had Tobin's q of less than one, that is, Slovenia had been on transition from 1991 (when she declared independence) to 2001, and then joined EU in 2004. Table 4 shows the average Tobin's q values for the selected countries.

This study presents, in Table 5, the marginal effects of knowledge absorption of Tobin's q. Marginal effect is found mathematically with the following expression (just for the knowledge):

$$
\frac{\partial y}{\partial x}=\lim _{h \rightarrow 0} \frac{f(x+h)-f(x)}{h}
$$

\footnotetext{
${ }^{22}$ See Appendix 1 adjusted market values of the companies and replacement cost of capital.
} 
Table 4. Average Tobin's q ratio for the selected countries.

\begin{tabular}{ccccccccccccc}
\hline \multicolumn{10}{c}{ Average Tobin's q ratio for the selected countries } \\
\hline Austria & Belgium & Cyprus & Denmark & France & Germany & Greece & Italy & Luxembourg & Slovenia & Switzerland & Turkey & United Kingdom \\
\hline 1.0117 & 1.0544 & 1.0583 & 1.0494 & 1.0622 & 1.0383 & 1.0489 & 1.03 & 1.1144 & 0.9928 & 1.1 & 1.0478 & 1.0956 \\
\hline
\end{tabular}

Table 5. Marginal Tobin's q ratio for the selected countries.

\begin{tabular}{|c|c|c|c|c|c|c|c|}
\hline Variable & Austria & Belgium & Cyprus & France & Germany & Greece & Italy \\
\hline$R \& D$ & 0.03 & 0.02 & 0.04 & 0.005 & 0.003821 & 0.03 & -0.033 \\
\hline \multirow[t]{2}{*}{$p$ value } & 0.01 & 0.00 & 0.05 & 0.796 & 0.837 & 0.053 & 0.045 \\
\hline & \multicolumn{2}{|c|}{ Luxembourg } & \multicolumn{2}{|c|}{ Slovenia } & \multicolumn{2}{|c|}{ Turkey } & United Kingdom \\
\hline Knowledge absorption & \multicolumn{2}{|c|}{0.01} & \multicolumn{2}{|c|}{0.00} & \multicolumn{2}{|c|}{-0.02} & $\begin{array}{l}-0.01 \\
0.635\end{array}$ \\
\hline$p$ value & \multicolumn{2}{|c|}{0.558} & \multicolumn{2}{|c|}{0.53} & \multicolumn{2}{|c|}{0.208} & 0.635 \\
\hline
\end{tabular}

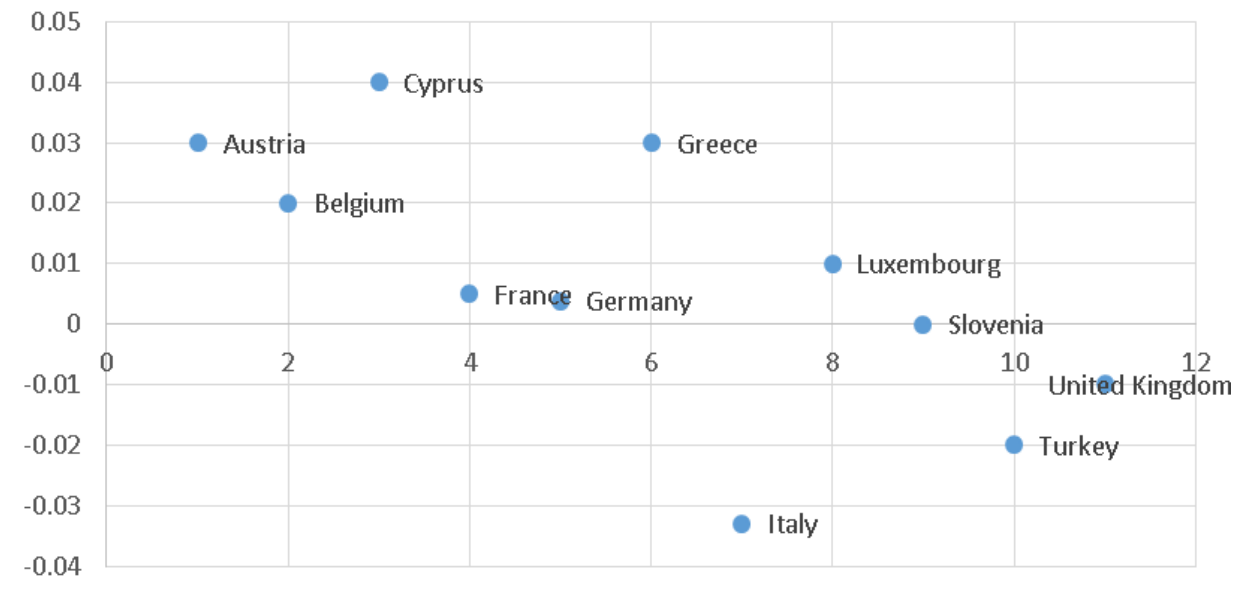

Graph 1. Marginal contribution of R\&D to Tobin's q.

In the equation, $f$ is predicted with only one argument. Marginal effect of $x$ is partial derivative with respect to $x$ variable.

Marginal effect counts for the effect of additional investment in R\&D (knowledge absorption). Graph 1 depicts the marginal contribution of R\&D to Tobin's q.

\section{RESULTS}

\section{Econometric estimation}

In this study, panel data sample was used, with 198 observations divided into 11 panels. Panel has a crosssection and time dimension (1993-2011). Because of the different variance that panels have, we decided that OLS is not an efficient estimator. Alternatively, we used FGLS (Feasible Generalized Least Squares). This estimator is applied when variances of the observations are unequal (that is, when there is heteroscedasticity). In such a case, OLS technique can be misleading and can lead to biased inferences.

From Table 6, we can see that R\&D investment and Tobin's $q$, that is, value of the firm divided by the replacement cost, are in positive and statistically significant relationship. Coefficient on knowledge absorption is of small size (0.005), but highly significant which is positive for its economic interpretation. Graph 2 shows Tobin's q for the selected countries and its movement from 1992 to 2012. It also shows a comparison of the benchmark country Austria with all other countries in the sample.

\section{Macedonian companies Tobin's q}

Because in Macedonia, stock exchange was established in 1995, Macedonian companies do have market 
Table 6. FGLS estimation with country effects.

\begin{tabular}{llll}
\hline Tobin's q & Coefficient & Standard error & P value \\
\hline Knowledge absorption & 0.005 & 0.002 & 0.027 \\
Countries & & & \\
Belgium & 0.042 & 0.008 & 0.000 \\
Cyprus & 0.064 & 0.010 & 0.000 \\
France & 0.045 & 0.007 & 0.000 \\
Germany & 0.017 & 0.008 & 0.029 \\
Greece & 0.043 & 0.007 & 0.000 \\
& & & \\
Italy & 0.015 & 0.007 & 0.021 \\
Luxembourg & 0.112 & 0.008 & 0.000 \\
Slovenia & 0.115 & 0.008 & 0.000 \\
Turkey & 0.042 & 0.007 & 0.000 \\
United Kingdom & 0.074 & 0.008 & 0.000 \\
Constant & 0.914 & 0.044 & 0.000 \\
Panels & & & \\
Number of observations & 183 & & \\
\hline
\end{tabular}

*Austria I benchmark country.

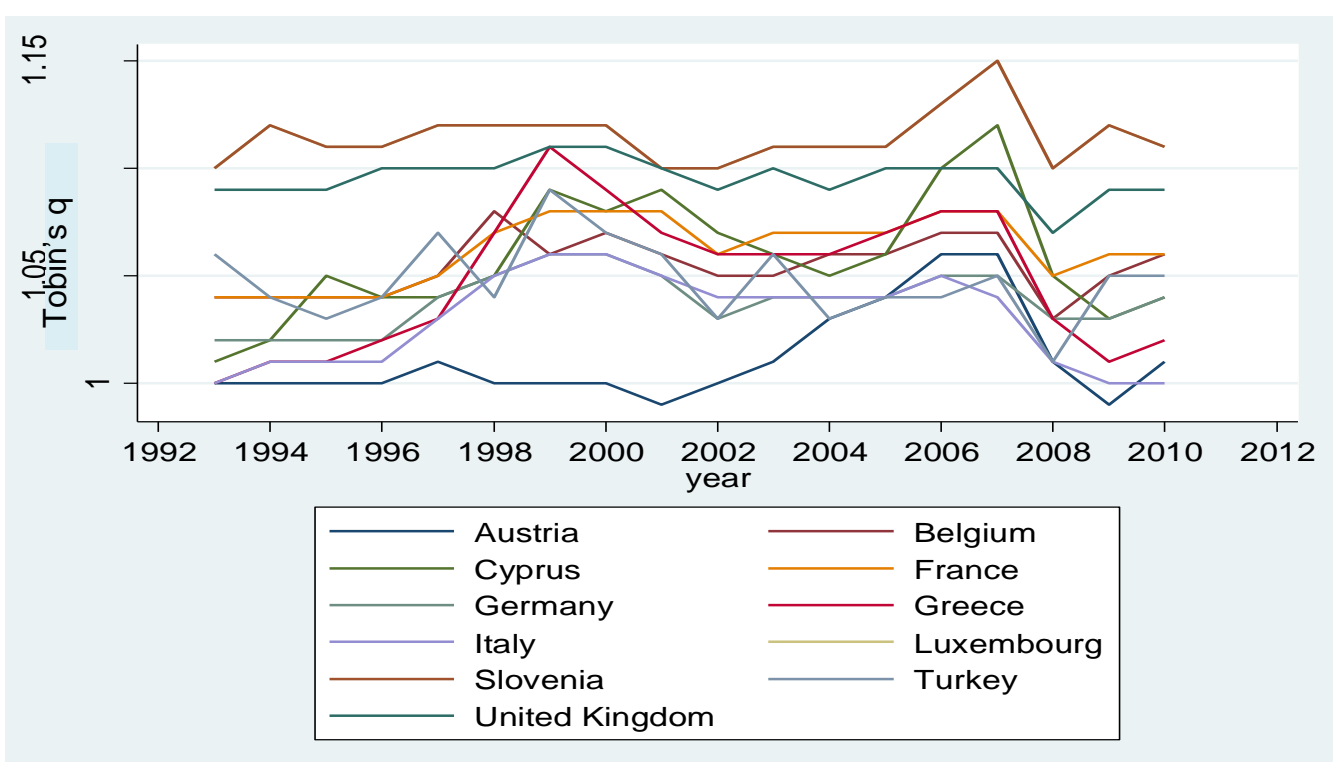

Graph 2. Tobin's q for the selected countries.

valuation data since 1996 onwards. In Table 7, data are presented for the market value of the total Macedonian companies listed on the stock exchange, and replacement value of the capital. Table 7 shows Macedonian companies market value (stock exchange listed), replacement value, Tobin's $q$ and knowledge absorption.
Since 2006, Tobin's q for Macedonian companies is close to 1 or $>1$. Before that, it was less than 1. It was observed that Macedonian company, since 1996, continuously increase their R\&D investment (knowledge absorption).

From Table 8, we can see that increase in knowledge absorption by $1 \%$ increases Tobin's q quotient by $0.23 \%$ 
Table 7. Replacement value of capital, market value of capital, Tobin's $q$ and R\&D of Macedonian companies.

\begin{tabular}{lcccc}
\hline Year & Replacement value & Market value & Tobin's q & Knowledge absorption \\
\hline 1996 & 8.68 & 7.99 & 0.92 & 6.45 \\
1997 & 8.77 & 6.90 & 0.79 & 6.35 \\
1998 & 8.72 & 6.90 & 0.79 & 6.38 \\
1999 & 8.73 & 6.88 & 0.79 & 6.74 \\
2000 & 8.71 & 6.85 & 0.79 & 6.75 \\
2001 & 8.72 & 7.66 & 0.88 & 6.74 \\
2002 & 8.76 & 8.26 & 0.94 & 7.01 \\
2003 & 8.92 & 8.56 & 0.96 & 6.84 \\
2004 & 8.99 & 8.62 & 0.96 & 6.97 \\
2005 & 9.02 & 8.81 & 0.98 & 7.02 \\
2006 & 9.01 & 9.04 & 1.00 & 6.94 \\
2007 & 9.14 & 9.43 & 1.03 & 7.29 \\
2008 & 9.19 & 8.92 & 0.97 & 7.40 \\
2009 & 9.22 & 8.96 & 0.97 & 7.31 \\
2010 & 9.00 & 9.42 & 1.05 & 7.25 \\
2011 & 8.50 & 9.40 & 1.11 & 7.39 \\
\hline
\end{tabular}

Table 8. OLS regression Tobin's q and knowledge absorption.

\begin{tabular}{lcc}
\hline Tobin's q & Coefficient & P value \\
\hline Knowledge absorption & 0.23 & 0.000 \\
Constant & -0.68 & 0.050 \\
R squared & & 0.6507 \\
Functional form (p-value) & \multicolumn{2}{c}{0.74} \\
\hline
\end{tabular}

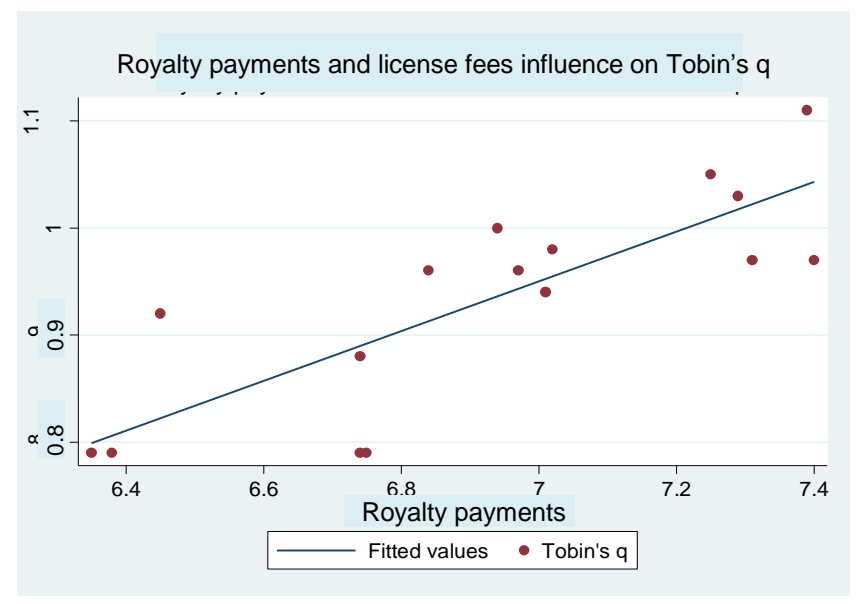

Graph 3. R\&D and Tobin's q of Macedonian companies.

points. This relationship is statistically significant at all levels of conventional significance ( $p$-value $=0.000$ ). Functional form also shows that if we reject the null of no omitted variables' bias, we will make Type I error. Next, we depict graphically Royalty payments and license fees trend with Tobin's q of Macedonian companies listed on
Macedonian stock exchange as shown in Graph 3.

\section{Conclusion}

From this paper, we concluded that there exist positive and statistically significant relationship between Tobin's q 
and investment in R\&D, or as we name it, knowledge absorption, according to the Global Innovation Index $2012^{23}$. This is one of the important conclusions from this paper.

\section{REFERENCES}

Abel BA (1984). "R \& D and the Market Value of the Firm: A Note". In $R$ \& $D$, Patents and Productivity, edited by Zvi Griliches, (1984), pp. 261-269.

Akerlof $G$ (2007). Missing motivation in macroeconomics. Am. Econ. Rev., 97(1): 5-36.

Arrow KJ (1962). "The Economic Implications of Learning by Doing," Am. Econ. Rev., 96(2): 308-312.

Bronwyn HH, Grid T, Salvatore T (2007). "The market value of patents and R\&D: Evidence from European firms,"NBER Working Papers 13426, National Bureau of Economic Research, Inc.

Cockburn I, Griliches Z (1988). "Industry Effects and Appropriability Measures in the Stock Market's Valuation of R\&D and Patents, "American Economic Review. Am. Econ. Asso., 78(2): 419-23.

Connolly R, Hirschey M (1984). R\&D, Market Structure and Profits: A Value-Based Approach. The Rev. Econ. Stat., 66(4): 682-686.

Connolly R, Hirschey M (2005). Firm size and the effect of R\&D on Tobin's q, R\&D Manage., 35. 2, 2005. cg Blackwell Publishing Ltd, 2005. Published by Blackwell Publishing Ltd.
Griliches Z (1981). 'Market value, R\&D and patents', Economics Letters, 7 (2), 183-187.

Griliches Z (1979). R\&D and Productivity: The Econometric Evidence, Chapter: Issues in Assessing the Contribution of Research and Development to Productivity Growth.

Hall BH, Lerner J (2010). "The Financing of R\&D and Innovation, "UNU-MERIT Working Paper Series 012, United Nations University, Maastricht Economic and social Research and training Centre on Innovation and Technology.

Hall B (1998). Innovation and market value, University California Berkeley.

Megna P, Klock M (1993). The Impact of Intangible capital on Tobin's q in the Semiconductor Industry. The Am. Econ. Rev., 83(2): 265-269.

Share WF (1964). "Capital Asser Prices: A Theory of Market Equilibrium under Conditions of Risk", J. Finance 19, September, pp. 425-442.

Tobin J, Brainard WC (1977), Asset Markets and the Cost of Capital, Cowles Foundation Paper 440

Tobin J (1969). "A general equilibrium approach to monetary theory". J. Money Credit Bank., 1(1): 15-29.

Warusawitharana M (2008). Research and Development, Profits and Firm Value: A Structural Estimation, Division of Research and Statistics, Board of Governors of the Federal Reserve System.

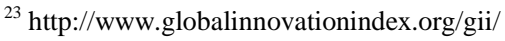

